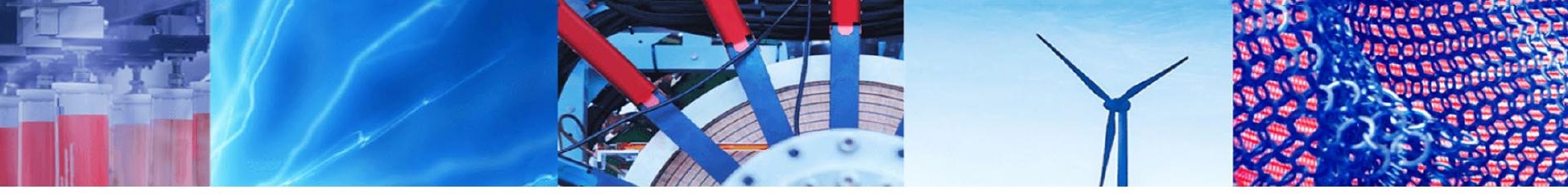

Case Study

\title{
Landslide in parts of southwestern Nigeria
}

\author{
O. A. Bamisaiye ${ }^{1}$ (D) \\ (c) Springer Nature Switzerland AG 2019
}

\begin{abstract}
Landslides represent "structural failures" with great risk to the environment, and this makes the study of the mechanism of formation of landslides very important. Most parts of the Okemesi ridge are inherently dangerous areas, at high risk of sliding. This research is one of the first detailed geological investigations of landslides in this area. This research evaluates the importance of the lithological, structural and geomorphological factors to landslide activities in parts of southwestern Nigeria with the aim of designing a susceptibility map which is intended to serve as an early warning and mitigation measures. The result revealed that the latest landslide was caused by the release of intensely fractured rocks along adjacent blocks of a fault plane, and prevalent tectonic stress condition set the stage for the landslide, while slope instability in conjunction with prolonged high-intensity rainfall triggered the movement. The most susceptible area of landslide is within the slope angles of between $45^{\circ}$ and $75^{\circ}$ with an elevation of between 514 and $666 \mathrm{~m}$. The research further revealed that the landslide occurred about $500 \mathrm{~m}$ to the road. The landslide-prone location is within the $0-200 \mathrm{~m}$ from the hill; hence, human settlements and activities should be sited at least $500 \mathrm{~m}$ away from the hill.
\end{abstract}

Keywords Landslide susceptibility · Graben $\cdot$ Joints · Stress trajectories · Slope

\section{Introduction}

Landslide can be defined as the mass movement of rock, debris or earth down a slope [1-3]. It is currently one of the most common natural disasters in the world. Landslide causes and triggers have attracted the attention of researchers for centuries, most especially as early warning and mitigation measures. The causes of landslide are those factors that rendered slopes vulnerable to failure, while triggers are factors that initiate the downslope movement or slide. The major triggering factors include both natural and human activities [4]. The natural triggering factors include precipitation and slope instability, while landslides that are entirely due to or aided by human activities such as construction, mining, quarrying and excavations remain on the increase all over the world [4-7]. Slow and steady decrease in rock strength due to fracturing, water infiltration into cracks and pore spaces, weathering, etc., are some of the causes. The record of Fatal Landslides in America between 2002 and 2007 [8] and between 2004 and 2016 [9] exceeds forty thousand occurrences. The high incidence of fatal landslides may be accredited to an increase in water level due to global warming and climate change $[10,11]$, deforestation due to development and urbanization, etc.

This research assesses the landslide susceptibility [12, 13] and quantifies the hazard and risk related to landslides in Okemesi, Southwest, Nigeria, using field mapping and inventory, remote sensing and geographic information system (GIS). This study highlights the lithology, proximity to fault, the presence of abundant foliation planes, the slope angle, the geomorphology, slope aspect, lineament frequency, joint orientations and distribution, orientation of observed geologic structures as major causative factors of landslides around Agboona Hill.

O. A. Bamisaiye, adunseyi@gmail.com, https://oabamisaiye.futa.edu.ng| ${ }^{1}$ Applied Geology Department, Federal University of Technology, PMB 704, Akure 340252, Ondo State, Nigeria.

SN Applied Sciences (2019) 1:745 | https://doi.org/10.1007/s42452-019-0757-0

Received: 21 March 2019 / Accepted: 11 June 2019 / Published online: 18 June 2019 
For this study, the lithology, the slope angle, the geomorphology, slope aspect, lineament frequency, joint orientations and distribution, orientation of observed geologic structures were considered as parameters in preparation of the susceptibility map $[12,13]$.

In Nigeria, there is the dearth of information on local landslide and slope instability problems and no systematic database of past landslide occurrences is available; hence, it is often difficult to predict and map landslides, due to the diversity and large volumes of data needed, and the complexity in the analysis procedures. In hilly terrains of Nigeria such as Okemesi, heavy rainfall, porosity of the soil and moisture content as well as slope angles facilitate the frequent occurrence of landslides that have destroyed lots of properties and infrastructures in the area. Consequent to the massive urbanization and land cultivation along the slope, which makes the area prone to landslide, residents are now gripped with the palpating fear that every time it rains heavily the slope will probably give way again [14]. In view of the considerable losses due to landslides, this study seeks to consider the occurrence of landslides in the area and find ways to mitigate the ensuing losses.

The Agboona Hill, Oja Titun, Okemesi-Ekiti landslide occurred within latitude of $7^{\circ} 48^{\prime} 30^{\prime \prime} \mathrm{N}$ to $7^{\circ} 56^{\prime} 30^{\prime \prime} \mathrm{N}$ and longitude of $4^{\circ} 53^{\prime} 0^{\prime \prime} \mathrm{E}$ to $4^{\circ} 59^{\prime} 30^{\prime \prime} \mathrm{E}$ during a period of intense rainfall in September 2017 [14].The area is part of the Okemesi fold belt ( $>150 \mathrm{~km}$ in length) and lies north of northeast of this megafold (Fig. 1).

Field evidence and interaction with residents indicate a minimum of three other previous episodes of landslide in years 1973, 1982 and 1993, respectively. The 1993 landslide occurred about $200 \mathrm{~m}$ away from the site of the most recent landslide. Imprints of damage to buildings by the 1993 landslide event are still visible in the area. However, it is believed that several unreported landslides might have occurred around the Okemesi Fold belt, especially in areas that are far from human settlement. The relics of old landslide are not discernable from aerial or satellite images because of the rugged topography and dense vegetation. In order to get around this problem, attempts were made to assess the area immediately the Agboona landslide was reported just before the onset of another raining season as the place will definitely become too vegetated for any clear investigation.

Several landslide occurrences in Nigeria are not recorded except when it leads to a major disaster.

According to [15], most landslides in southern Nigeria are due to the loose nature of sedimentary rocks coupled with the impact of gully erosion created by heavy rainfall and subsequent flooding. For example, it was reported that landslides occur mostly as earth movement, in the Ogbajala hills of Benue State on September 3, 1987, after days of continuous rainfall and subsequent flooding [16,

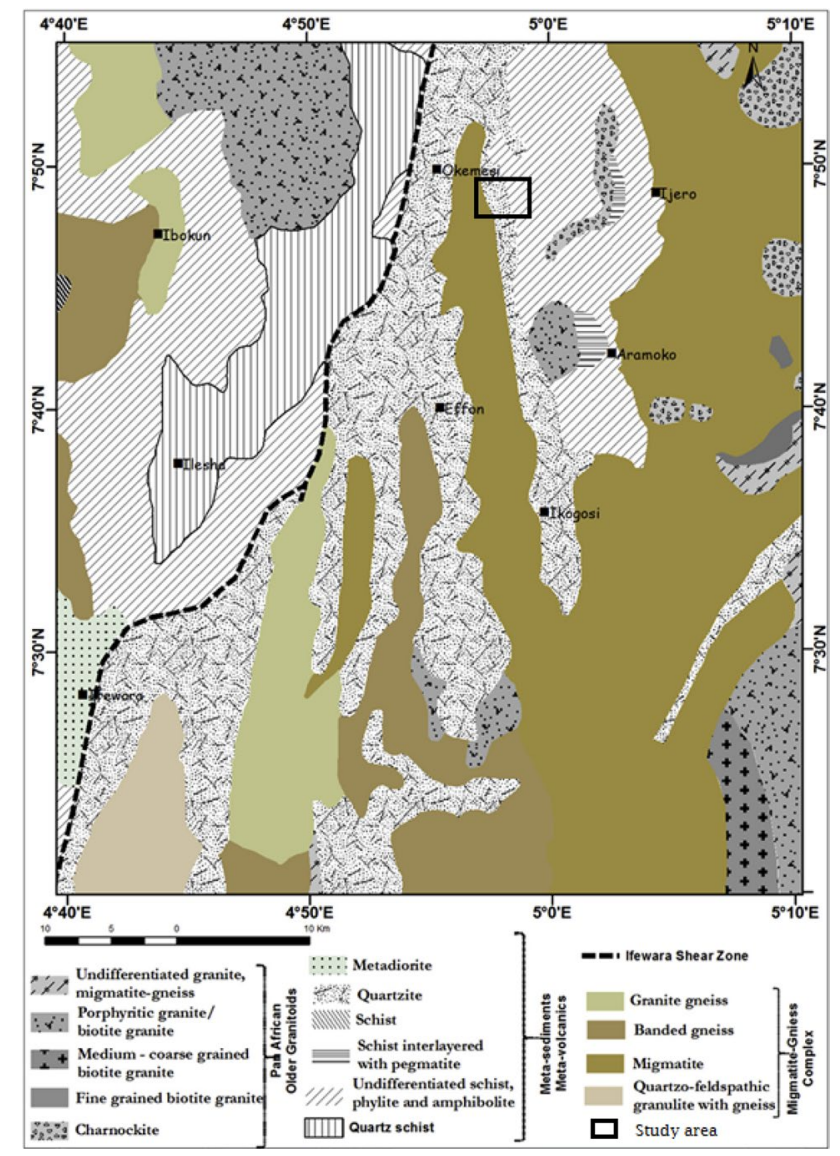

Fig. 1 Geological map of Okemesi. Modified after [26]

17]. Another landslide occurred, in September 1997, along the slope of the Akovolwo mountains near Jato-Aka in Kwande Local Government area of Benue State [18].

This landslide is associated with graben failure. The linearity of the graben failure zone and the presence of wellpolished and mylonitic rocks suggest a fault zone. Dip on the two hanging blocks is between $65^{\circ}$ and $80^{\circ}$ (Fig. 2). A well-developed graben with a prominent, southwest facing scarp, and more subdued, northeast-facing scarp crosses the ridge (Fig. 2). Between these scarps is an elongate depression (extends approximately $35 \mathrm{~m}$ ) and forms the axis of the graben. The sliding direction along the dip slope is indicated by large striations and grooves observed on the sliding surface, which trend $\mathrm{E}-\mathrm{W}$. The distance travelled by the debris is approximately $400 \mathrm{~m}$.

There are several different interpretations of the origin of ridge-top grabens given by [19-23]. These authors attributed the graben formation to seismic-related shaking from earthquakes on strike-slip and thrust faults. Some of the structural features observed around the landslide site include normal faults, joints, recumbent folds, strike-slip faults and thrust nappe. These fractures are considered important for creating weak zones with high permeability 


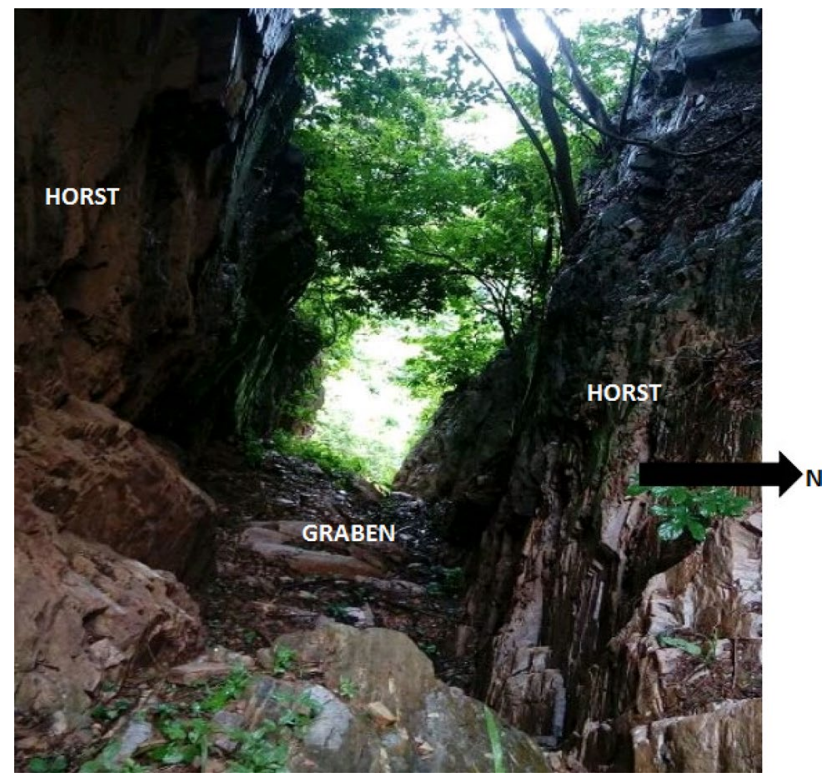

Fig. 2 Photograph of the landslide site showing horst and graben structure with arrow pointing to the north. The strike and dip of the horst blocks are $092^{\circ} \mathrm{SE} / 72^{\circ} \mathrm{W}$ (north) and $145^{\circ} \mathrm{SE} / 50^{\circ} \mathrm{W}$ (south)

and high rate of weathering which makes the area susceptible to landslide.

The landslide in Agboona Hill, probably initiated with the development of parallel normal faults along the horst, further weakening of this zone by fracturing, water infiltration and gravity led to shattering of rocks along this zone. However, numerous open fractures joints, cracks, folds and high strain shears were encountered on the ruptured surfaces. Borehole and geophysical data that can help to verify the influence of earthquake were not available at the time of compiling this manuscript. However, most of the rock fragments displaced by the landslide show wellpolished surfaces, suggesting that the dominant processes along this fault zone are bulk crushing, surface grinding and polishing.

\section{Geological, geomorphological and structural characteristics of the area}

\subsection{Local geology}

The study area is part of the Okemesi fold belt, which is also part of the basement complex rocks of Nigeria, is characterized by highly fractured quartzite, quartz schist, mica schist, mylonite and a thin sedimentary cover. The quartzite is massive, milky and has varying textures from equigranular to medium grain. [24] from geochemical studies suggest sedimentary source for the schistose rocks. The quartzite is highly fractured due to the high degree of tectonism that has taken place in the area. The quartzite consists of quartz which is usually more than $70 \%$ with minor amounts of interlocking grains of biotite. The quartzite in this area has orange-yellow color due to mineral impurities. The study area is underlain by crystalline rocks of the Precambrian basement complex of southwestern Nigeria.

The study area consists of long, linear, subparallel, hogback ridges with rugged relief and elevation of approximately $599 \mathrm{~m}$ above the surrounding terrains. Topographically, the study area lies between two ridges running approximately north-south, which adjoin close to the northern boundary and form the east and west limits of the undulating valley and lowlands. Many researchers had studied the geology of different parts of Okemesi fold [24-27]. The Agboona Hill is characterized by westwarddipping sections, with NNW-SSE foliation trend.

\subsection{Local structures}

Structurally, the quartz schist is jointed and foliated. Quartz vein, joint and fold are the dominant structural features of the rocks in this locality, the quartz schist exhibits alternations of felsic mineral such as quartz and mafic mineral such as biotite with planar fabric $[24,28]$. The foliation type is schistosity defined by the preferred orientation of quartz in the quartz schist and also the preferred orientation of highly strained quartz grained.

The area is also part of the regional Dahomeyide fold belt defined by [25] and has imprints of the structural and deformational episodes that pervaded Nigeria's Precambrian basement complex. These rocks were reworked by multistage deformation, which resulted in several stages of folding, shearing and fracturing of the metamorphic rocks. Within the basement complex, tectonic deformation has completely obliterated primary structures [28] except in a few places where they survived deformation [29]. The Ifewara fracture zone separates the rock of llesha schist belt into two structural units of contrasting lithologies [30-36]. Other workers [37-40] have provided evidence in support of the existence of the structure as well as its significance in terms of tectonic movements. Also, sutures have been proposed along the two transcurrent fault zones, in particular within the Ife-llesha schist belt, which has been interpreted as a back-arc marginal basin [39], and east-verging nappes [40].

\section{Methodology}

A detailed field observation of the fault zone and the general terrain was undertaken to investigate the triggering mechanism and the relationship between the landslide, 
the observed geologic structures and the stress trajectories. Measurement of attitudes and collection of oriented samples for petrographic studies was taken. Field observations at different scales were performed along the sliding surface, the fault planes, the landslide deposit and the outcrops around the landslide. The geomorphological analysis is performed by means of the interpretation of satellite images obtained from Google Earth and the Digital terrain model [DEM (Fig. 3)] (acquired by Shuttle Radar Topographic Mission with $30 \mathrm{~m}$ spatial resolution (1 ArcSecond)) as well as slope measurements in the field. ArcGIS 10.4.1 GIS software was used for rasterization of images, for creating personal geodatabase and Shapefiles used in performing the overlay function. ENVI software was used to filter the DEM. The PCI Geomatica software was used to extract lineaments. Data on joint orientation and distribution were directly collected from the field and presented in the form of rose diagram. Inventry method of field data collection was adopted. A representative region was defined, and measurement of all the joints within the region was taken by marking out squares on the outcrop and measuring all the features within each squares. Lines were drawn across the outcrop, and all the joints that cut across the lines were measured. This method was used to determine the fracture density in the rock and carry out a statistical analysis of the joint data. Other factors considered for landslide susceptibility mapping are slope, slope aspect, elevation, distance to fault, lineament and lineament density. The importance and method of investigation of each factor are as follows:

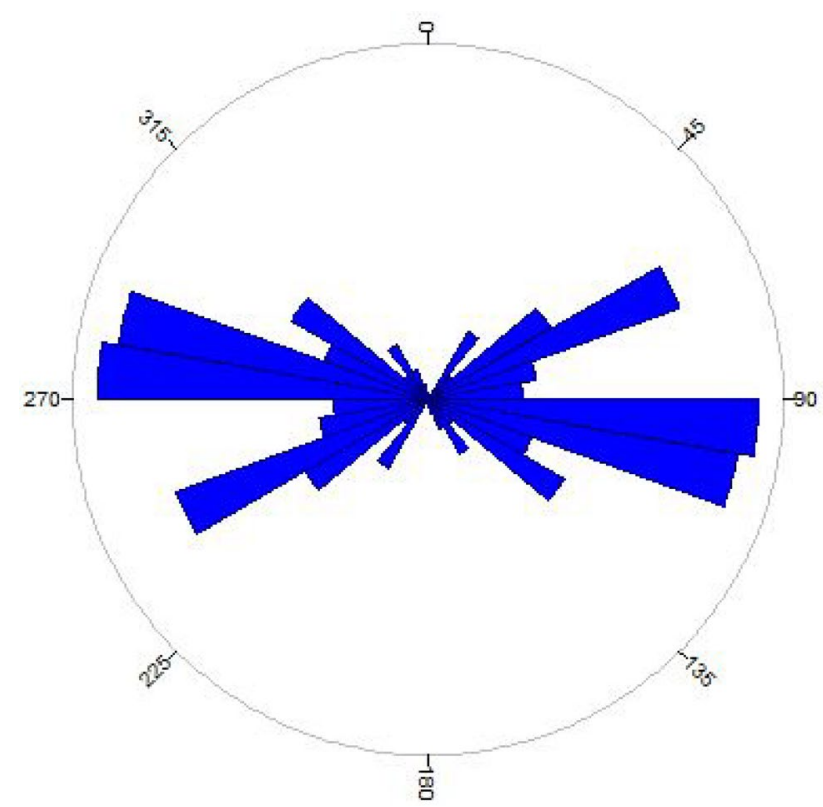

Fig. 3 Rose diagram showing analysis of joint orientations. The dominant orientation is $\mathrm{E}-\mathrm{W}$

\subsection{Slope}

The slope angle is frequently used for preparing a landslide susceptibility map [41-43]. For this study, the slope angle was considered as a major parameter in slope stability. The slope is the measure of surface steepness measured in degrees or percentage. It has a range between $0^{\circ}$ and $90^{\circ}$, where $0^{\circ}$ represents the flat and $90^{\circ}$ represents the vertical areas. The slope map of the study area was divided into five classes. A slope raster map was reclassified, and a reclassified value was then given to each of the slope factors ranging from 0 to 100 . This value was based on the contribution of each factor as it affects landslide (Table 2).

\subsection{Slope aspect}

Slope aspect is defined as the direction of maximum slope of the terrain surface with reference to north; it is an important factor in preparing landslide susceptibility maps [41-44]. The layer for slope aspect was also derived from the DEM. It represents the angle between the Geographic North and a horizontal plain for a certain point and it is classified into eight major orientations. The slope aspect of the study area is classified into ten classes including the flat areas: flat $\left(-1^{\circ}\right)$, north $\left(0^{\circ}-22.5^{\circ}\right)$, northeast $\left(22.5^{\circ}-67.5^{\circ}\right)$, east $\left(67.5^{\circ}-112.5^{\circ}\right)$, southeast $\left(112.5^{\circ}-157.5^{\circ}\right)$, south $\left(157.5^{\circ}-202.5^{\circ}\right)$, southwest $\left(202.5^{\circ}-247.5^{\circ}\right)$, west $\left(247.5^{\circ}-292.5^{\circ}\right)$ and northwest $\left(292.5^{\circ}-337.5^{\circ}\right)$ north $(337.5-360)$.

\subsection{Elevation}

Topography firstly controls the spatial variation of hydrological conditions and slope stabilities [44]. Elevation data were obtained from the digital elevation model (DEM) in a resolution of $30 \mathrm{~m}$ derived from the $10 \mathrm{~m}$ interval digital contour lines and elevation points.

The slope angle, slope, slope aspect, plan curvature, profile curvature and elevation data were extracted from the digital elevation model (DEM) of part of the Okemesi fold belt. This task is implemented in ArcGIS. The digital elevation model (DEM) acquired by Shuttle Radar Topographic Mission with $30 \mathrm{~m}$ spatial resolution (1 Arc-Second) was used for lineament extraction.

\subsection{Distance to fault}

The latest landslide occurred along a fault zone, which is a zone, of weakness characterized by heavily fractured rocks with high permeability and intense shearing. Proximity to the structural elements (e.g., active fault) is very important contributing parameter in the evaluation of landslide 
susceptibility [44, 45]. Conforti et al. [46] described fault lines as area of weakness with high incidence of slope failure.

Fault lines were derived from extraction of lineaments of the study area, followed by the creation of buffer zones in ArcGIS. Proximity to fault line was calculated using GIS spatial analyst functions. It should be noted that the width of fault is not considered for statistics due to data unavailability. The distance from fault is calculated at $200-\mathrm{m}$ intervals using the lineament map.

\subsection{Lithology}

Different lithological units have different susceptibility degrees $[41,47]$. The lithological map of the study area was investigated by field mapping and incorporated with the existing geological map obtained from the Nigeria Geology Survey. The existing map was scanned and uploaded into the ArcGIS environment and carefully updated.

\subsection{Faults and lineaments}

The lineaments represent fractures, discontinuities and shear zones, interpreted from the combination of the DEM and satellite image. Lineament detection was facilitated by application of image filtering and edge detection techniques. Sobel and gradient filtering was applied using ENVI (Exelis Visual Information Solution 2013). The combined Sobel image and gradient image were then used for lineament extraction. Semi-automated approach was used which gives a result consistent with previous reports for the area.

Lineament extraction was performed using a LINE module of PCl Geomatica software [48]. The LINE module has many advantages over most the Hough transform and other methods of edge detection $[49,50]$. Additionally, the canny edge detection applied in LINE module of $\mathrm{PCl}$ gives least false positives when compared with other methods [51]. Spatial distribution of lineaments was examined by further converting the extracted lineaments to a measurable quantity of lineament density. Lineament density is defined as the total length of lineaments per unit area, whereas frequency indicates the total number of lineaments per unit area $[52,53]$. The lineament density was computed using the equation

$L d=\sum_{i=1}^{i=n} \frac{L_{i}}{A}\left(\mathrm{~km}^{-1}\right)$

implemented through the line density function in spatial analyst extension of ArcGIS [53, 54].
Here, Ld is defined as the total lengths ( $L i)$ of all recorded lineaments divided by the area $(A)$ under consideration. For computation, a circular area $(A)$ around each pixel was considered. All lineaments that plot into the circular neighborhood around each cell were incorporated into the computation of $L d$ in each cell. The radius of the circle around each pixel (1850.64 m) was determined by dividing the width of the study area $(24 \mathrm{~km})$ by $30 \mathrm{~m}$ which is the resolution of the pixel cell. The results were generated as raster with $30 \mathrm{~m}$ cell size over the study area.

All the landslide susceptibility factors were integrated by assigning a weightage ranked value in order of significance for each factor and then averaged (over the whole study area) to produce the landslide susceptibility map.

\section{Results}

\subsection{Estimated volume of material moved}

The regional strike and dip of the ridge are $182 \mathrm{SW} / 84 \mathrm{~W}$. The width (i.e., the space between the two blocks formed by the landslide) varies, and they are as follows: $1.90 \mathrm{~m}$, $2.90 \mathrm{~m}, 3.05 \mathrm{~m}, 3.50 \mathrm{~m}, 6.10 \mathrm{~m}, 7.0 \mathrm{~m}$, the height of the blocks affected by the landslide is approximately $15.50 \mathrm{~m}$, and the length of the landslide is approximately $32.20 \mathrm{~m}$. To calculate the volume of materials moved during the landslide, the length, depth and average width of the landslide scar were determined and the volume can be determined according to the formula below [27].

$V=1 / 6 \pi(D * W * L)$

where $V=$ volume of the materials generated from the landslide, $\pi$ is a constant, $3.142, D=$ depth of the landslide, $W=$ average width of the landslide, $W=(1.90+2.90+3.0$ $5+3.50+6.10+7.0) / 6=4.075$ and $L=$ total length of the landslide.

Therefore, the volume of materials moved from the landslides,

$V=0.1667 * 3.142(15.50 * 4.075 * 34.60) \mathrm{m}$

$V=0.5237(2185.42) \mathrm{m}$

$V=1144.51 \mathrm{~m}^{3}$

\subsection{Structures observed}

\subsubsection{Joints and plumose structure}

Joints are natural breaks in rocks with no apparent or measurable movement parallel to the surface of the joints. Joint occurrence is prominent in most consolidated rocks such as quartzite and granites. They are common in many tectonic environments, although the stress origin of the 
joints might be contentious. However, the spatial orientation of joints could indicate the directions of the principal stresses operative during a compressional regime. Shear joints may be used to estimate the orientation of a principal tectonic stresses operating in an area based on Coulomb criterion [43]. Joints play significant role in the development of landslides. It is postulated that the directions of tectonic stresses significantly control the orientation and forms of failure planes in the landslides. Joint pattern on rocks is one of the ways by which stress trajectories can be determined. The landslide failure surface parallels the joint orientation and the steeper side of the hill. Some of the joints on the outcrop are non-systematic. Most of the joints are parallel to the foliation planes of the outcrop, while few are perpendicular to the foliation. The analysis shows the highest frequency is within 81 to 100 and the dominant trend is E-W (Fig. 3).

Relic plumose structure preserved on the fracture surface (Fig. 4) shows a feathery Mode 1 (one) joint surface with $\mathrm{E}-\mathrm{W}$ propagation direction. This is interpreted as the intermediate stress axis $\delta_{2}$. This structure reveals the direction of joint propagation to be $\mathrm{E}-\mathrm{W}$, and it was produced due to the changing intensity of the stress field at the tip during the growth of the joint. The stress intensity is proportional to the length of the crack. The Plumose structure is formed when an unexposed joint surface revealed a rough pattern resembling the imprint of a feather. The stress intensity is proportional to the length of the crack.

\subsubsection{Veins}

The veins on this outcrop are mostly parallel to each other, while some are folded. Some have also resulted in the faulting. Some folds also occurred as echelon veins, i.e., short, parallel mineral-filled (typically quartz) lenses within rock formed as a result of tension fractures parallel to the major stress of the area. Analysis of the

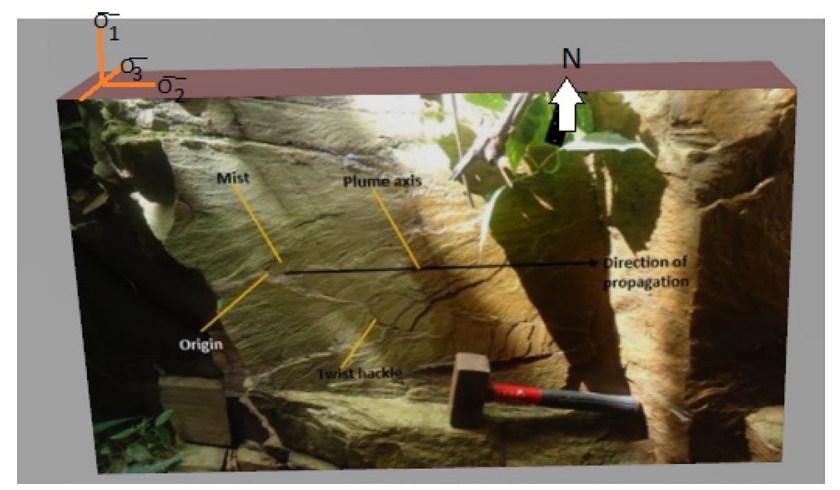

Fig. 4 Analysis of the stress directions. After van der Pluijm and Marshall [57] orientation of the vein shows the high frequency of the orientation of the veins as $137^{\circ}$ to $140^{\circ}$. Some of the veins are folded, and some faulted due to shearing, while some occur as echelon veins. In relation to the folds, most of the joints developed parallel to the axial planes and can be said to be longitudinal joints. A few of the joints developed normal to the fold axis as cross-joints.

\subsubsection{Foliation}

The foliation on the outcrop is defined by the preferred orientation of quartz in the quartz schist, and also the preferred orientation is due to highly strained quartz grained. Analysis of the strike and dip data measured and recorded in the field reveals a tectonic foliation which is a product of stress and strain from polyphase deformation of the rocks. The foliations are mostly schistosity and forms cleavages in places (Fig. 5). Foliation trends are dominantly E-W.

\section{Landslide susceptibility factors}

Apart from the afore-mentioned factors, other factors considered in classifying the susceptibility of the study area are elevation, slope, slope aspect, lineament, lineament density and distance to fault. The result of each factor is presented below.

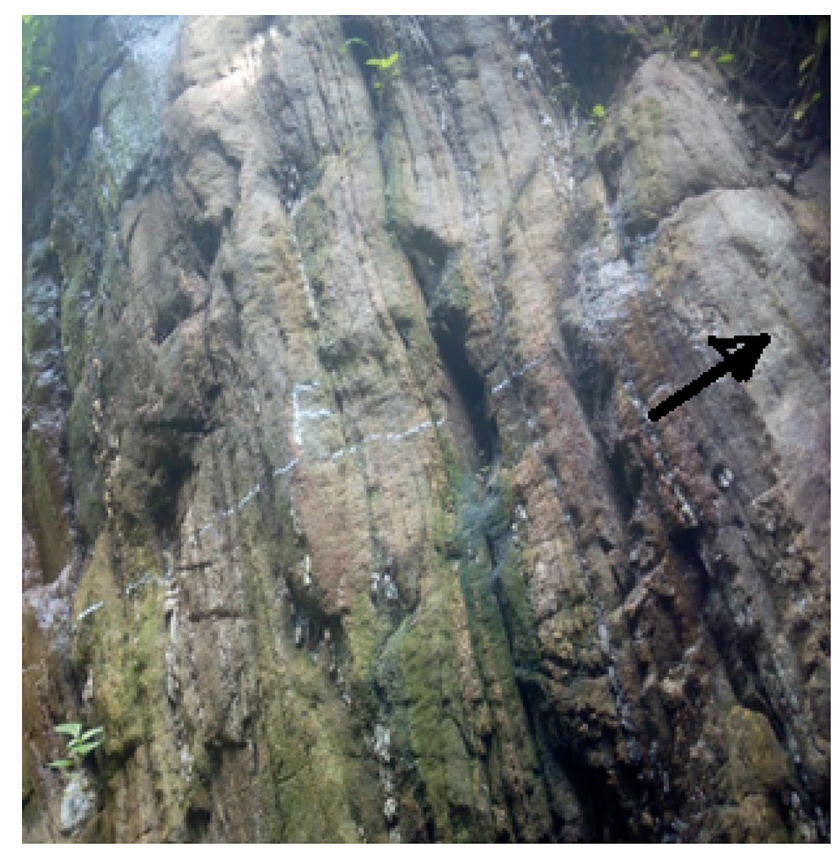

Fig. 5 Foliation planes with E-W trend 


\subsection{Elevation and other geomorphological features}

Topography is one of the most important factors in landslides susceptibility assessment, and the study revealed that the present landslide occurred within the steep slope in the area within an elevation of between 514 and $518 \mathrm{~m}$ (Fig. 6). Synoptic view of the landslide on satellite images is hampered by the small coverage of the area affected by the landslide compared to the size of the Okemesi fold belt. Also topographic evidence of landslides such as scarps, hummocky terrain, lobate toes and slopes along the ridges is obscured due to the thick vegetation cover.

\subsection{Slope}

The slope angle represents (Fig. 7) the gravitational force component and as such regulates mobilization vectors within a hill slope [55]. Studies had shown that landslides mostly occur at certain critical slope angles $[56,57]$. The transverse slope profile is an important variable that controls the superficial and subsurface hydrological regime of the slope [58]. The slope values in the study area range between $0^{\circ}$ and $75^{\circ}$ (Table 1). The slope of the study area was divided into five slope angle (Table 2 ) categories in order to accurately distinguish the degrees of steepness, and the areas with low angles are gentle to flat, while the areas with high angles are steep to very steep. The landslide in the study area occurred at a $60 \%$ and $80 \%$ in the reclassified slope and narrow ridge. Materials made up of rock debris mixed with mud transported down slope after the prolonged rain the weakened the slope.

\subsection{Slope aspect}

Slope aspect identifies the downslope direction of the maximum rate of change in value from each cell to its neighbors. It can be thought of as slope direction. In this study, the slope aspect map of the study area was produced from the DEM to show the relationship between slope aspect and landslide. The current landslide occurred southwest slope aspect class, which is also related to slope angle (Fig. 8). Slope aspect is related to parameters such as exposure to sunlight, winds (dry or wet), rainfall (degree of saturation), soil moisture and discontinuities which influence the occurrence of landslides.

\subsection{Lineaments and faults}

The rocks in the area have undergone different orogenic episodes and as a result responded differently to the tectonic deformation that has affected the terrain; hence, the numbers and sizes of lineaments (fractures)

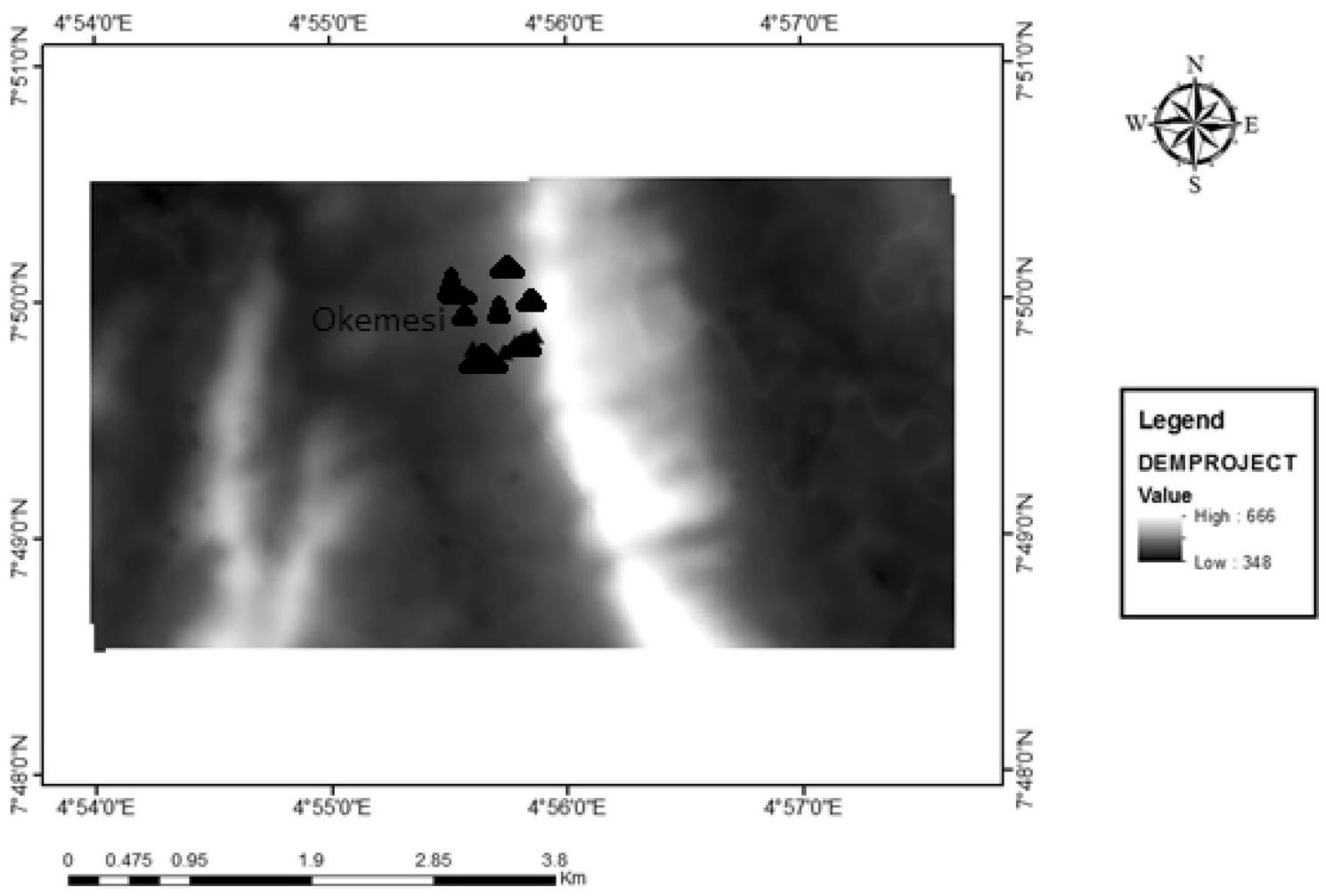

Fig. 6 Digital elevation model of the study area showing the elevation 


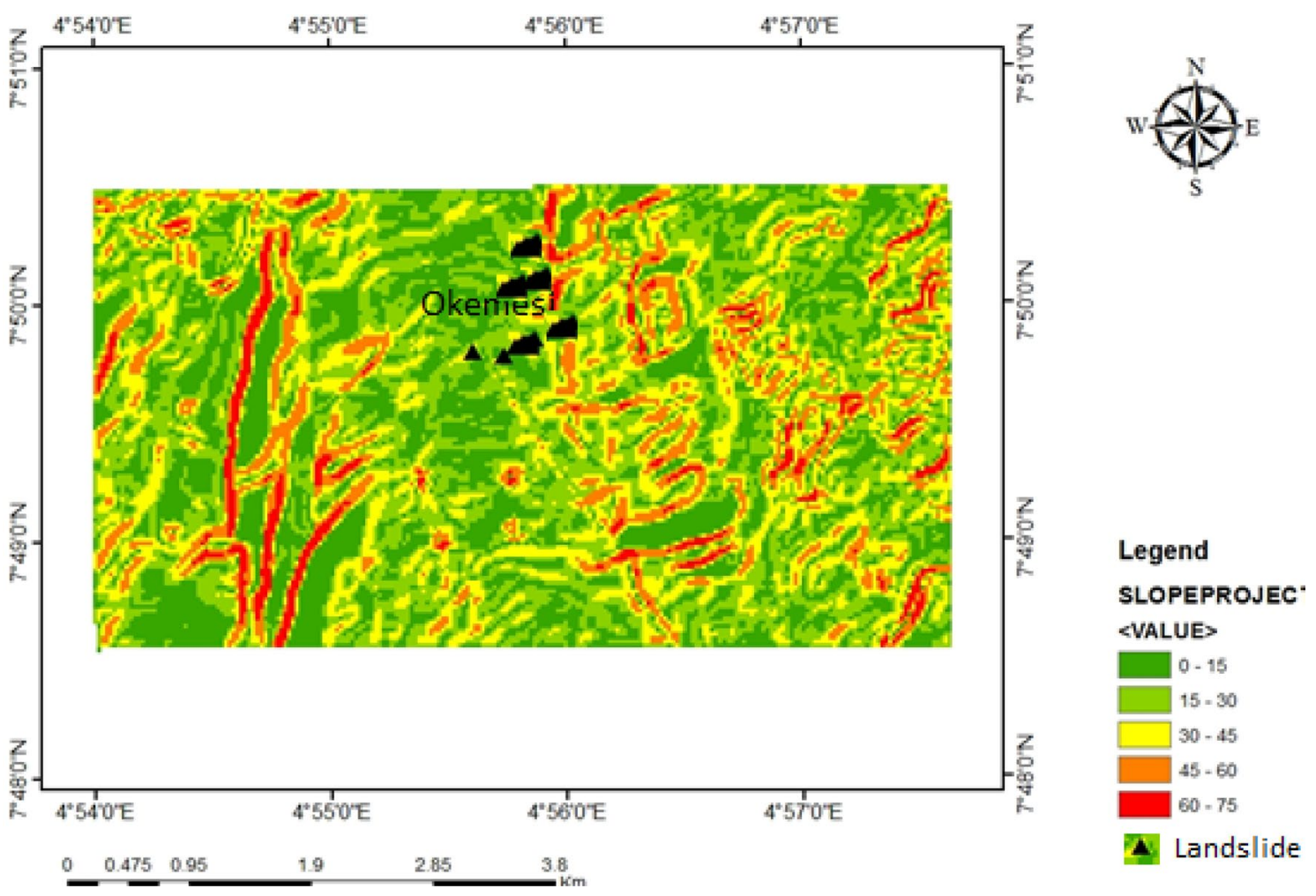

Fig. 7 Slope map of the study area

Table 1 Slope distribution in the study area

Table 2 The reclassified value for slope

\begin{tabular}{lll}
\hline Slope value & Rank value & $\begin{array}{l}\text { Reclas- } \\
\text { sified } \\
\text { value }\end{array}$ \\
\hline Flat & 5 & 20 \\
Gentle & 4 & 40 \\
Moderate & 3 & 60 \\
Steep & 2 & 80 \\
Very steep & 1 & 95 \\
\hline
\end{tabular}

were extracted from the different lithologies. Based on the computed lineament density (Fig. 9), areas underlain by quartzite are those with the highest density of lineament.

\begin{tabular}{ll}
\hline Slope class & Slope in degrees \\
\hline Flat & $0-15$ \\
Gentle & $15-30$ \\
Moderate & $30-45$ \\
Steep & $45-60$ \\
Very steep & $60-75$ \\
\hline
\end{tabular}

SN Applied Sciences

\subsection{Landslide susceptibility map}

The landslide susceptibility map was produced based on the factors discussed in the methods of study above. Figure 9 shows the final landslide susceptibility map of the study area. From the map, the blue area predicts areas with very low landslide susceptibility, the turquoise area predicts areas with low landslide susceptibility, the green shade predicts moderate susceptibility, the orange shade predicts high susceptibility of landslide, and the salmon shade predicts very high susceptibility of landslides. The result shows that current landslide and the most susceptible areas to landslides are within the areas with high slope. From field evidences, the susceptibility of this area to landslide is aided by (i) the increased volume of water within the rock due to intense rainfall and (ii) the slope and gravitational collapse of fractured and weathered rocks from the fault zones. Human activities such as deforestation, construction, farming and settlement expansion contributed to incidences of landslides in the area. In these areas, the impact of rainfall induced flood water is high and slope failures are very predominant. There is also the widespread occurrence of deep and wide gullies in this area, as more and more sloppy grounds can cave in after being weakened by the impact of rainfall. Areas that are about average, less or least susceptibility are found mainly 


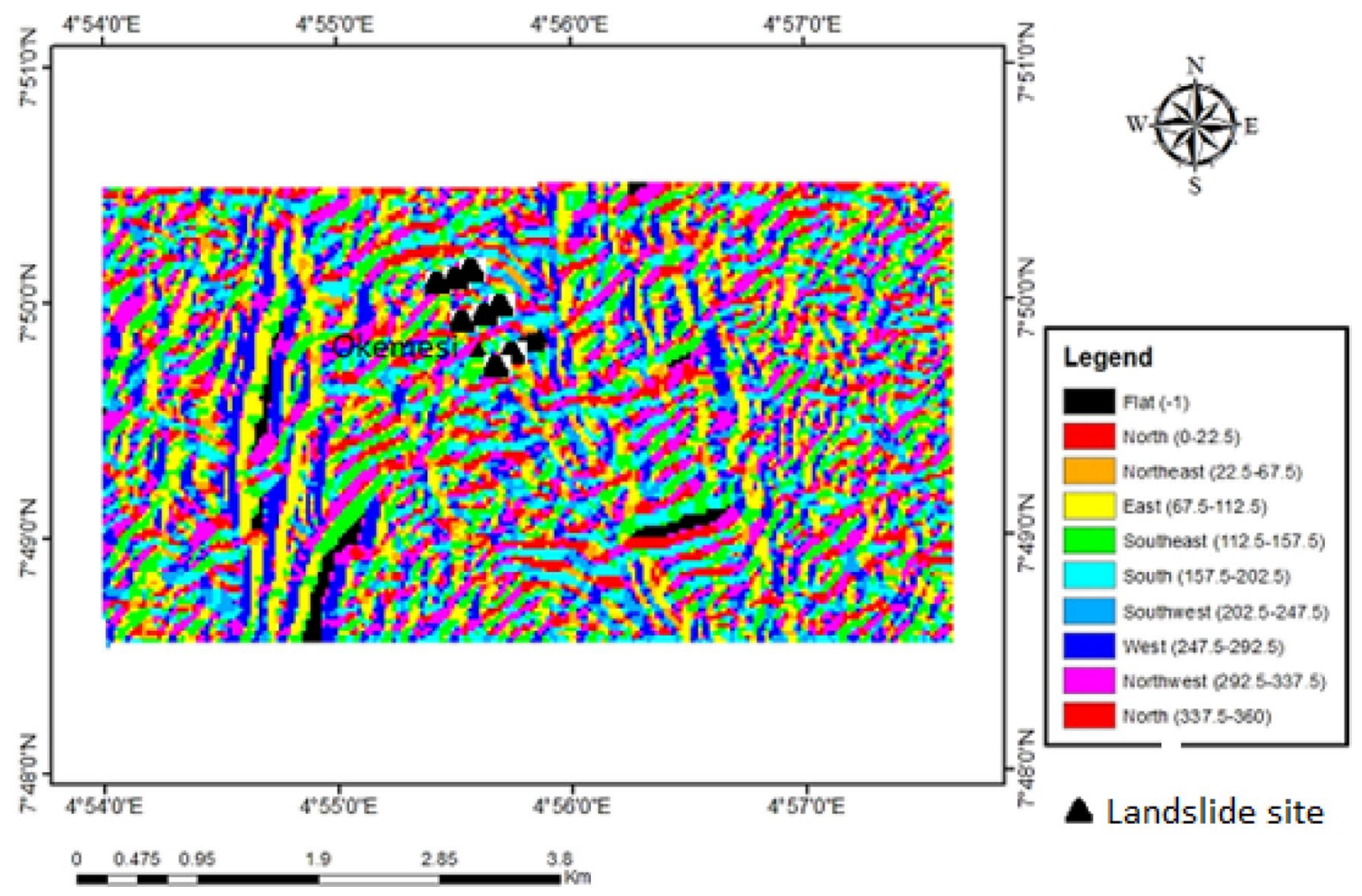

Fig. 8 Slope aspect map of the study area
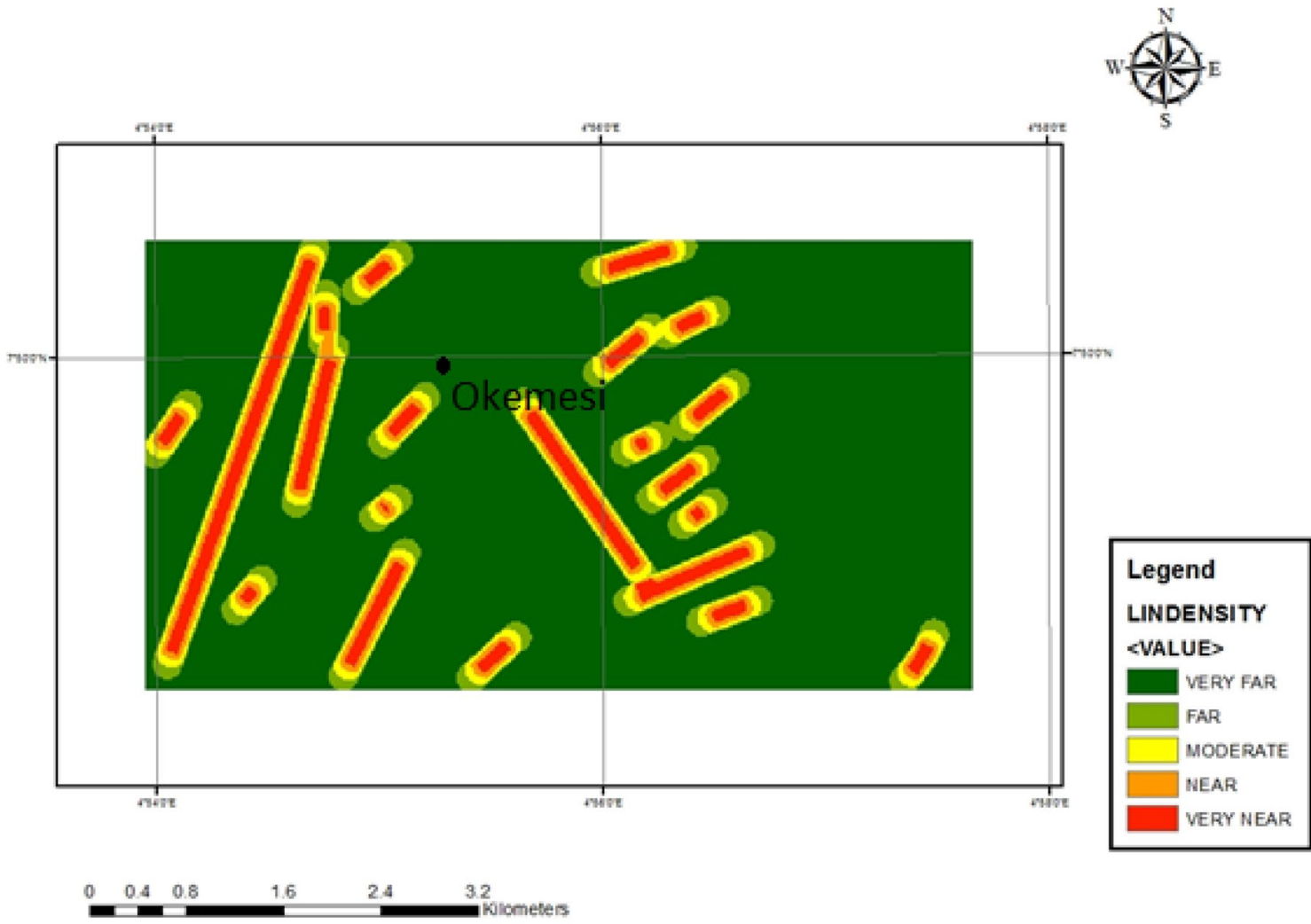

Fig. 9 Lineament density map in cooperation with the faults and major fractures 
in the low-lying grounds. The effect of the landslide in the area is shown in Fig. 10.

\section{Discussions and conclusions}

The result of the spatial inventory of slope analysis of the Okemesi Fold ridge indicates that more landslides occur in this area than what is reported. From the few reported landslide cases in the study area, the landslide mostly occurs during or immediately after the rainfall. Though rock deformation and water infiltration are the main triggering factor for the initiation of landslides in the area, tectonic stresses prevailing in the area and the orientation of joints are the main controlling factors for the spatial distribution of landslides in the area probably due to faulting and geotechnical characteristics of the prominent rocks in the area. In this study, the structure of the fracture network in the exposed part of Agboona hill has been evaluated on the basis of field observations. The exposed fault zone has a hackled appearance made up of an array of major pinnate joints. The graben and horst structures indicate a tensional environment and hence the numerous joints. The study of joints is important in landslide susceptibility mapping.
The landslides in the area occur along the dip direction of the planar features, and the most conspicuous feature of the orientation of the slip direction of all the landslides is that there exists a systematic trend between tectonic stresses, orientation of joints and slip directions of landslides [59-62]. The slip direction of the landslides is along the intermediate stress axis $\delta_{2}$, i.e., E-W (Figs. 3,4, 5), and the minimum stress axis $\delta_{2}$ but not in any case along the maximum stress axis $\delta_{1}$. The tectonic stress directions and the orientation of joints in the area correlate well. Thus, in this area, the orientation of stresses appears to have a profound influence on the incidence of landslides. The outcome of this work implies that in the mountainous terrain, particularly in the Okemesi fold area is active. This is well exemplified by the frequent occurrence of landslides in the region. Though on-spot geotechnical studies may be helpful to know the engineering properties of soils and rocks involved in the sliding phenomenon, the principal tectonic stress patterns and their orientation (Fig. 4) are useful in determining the dominant slip directions of landslides.

Secondly, the relationships between the stress and slip direction of landslides can be inferred as E-W from the analysis above. This will provide important additional information on landslide mechanisms in other parts of the ridge. Equally, such relationship may predict changes

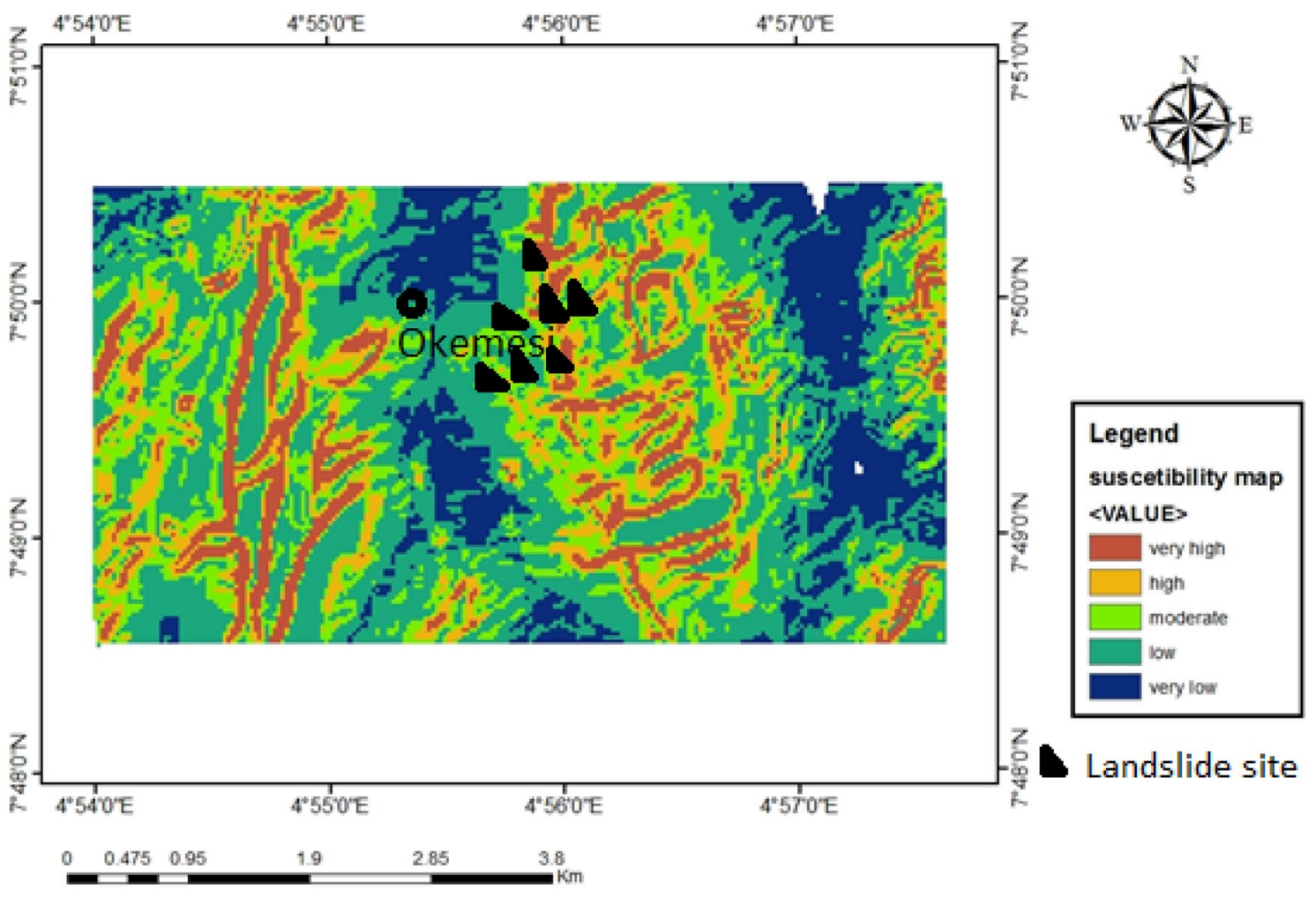

Fig. 10 Part of the study area showing the extent of landslide damage to properties 


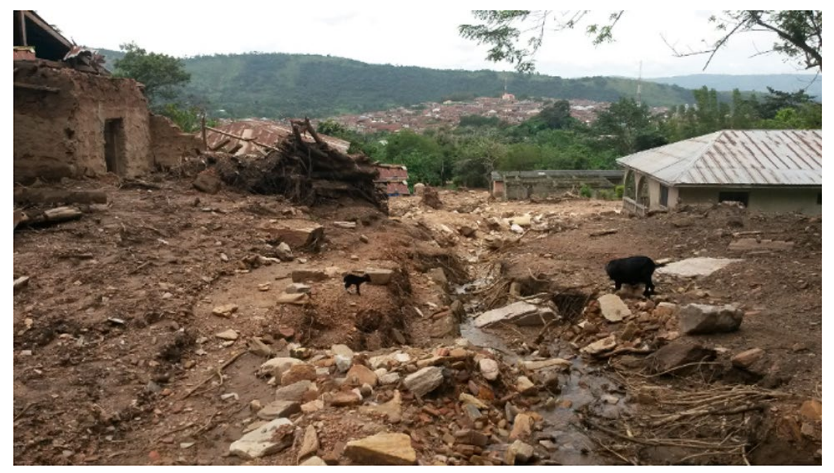

Fig. 11 Landslide susceptibility map with all the factors integrated

in mass movement activities throughout the fold region based on the stress patterns.

Three sets of foliation-perpendicular joints in the study area were identified in the field. These joints and foliations at each site indicate that most of the penetrative joint sets developed in the earlier tectonic stage of the pre-folding/ pre-tilting event, while some of the joints developed during the folding event.

The landslide susceptibility map (Fig. 11) can be used as a baseline data in identifying areas that are prone to landslides for early warning. As part of measures to mitigate against future damage, buildings should be located at least $500 \mathrm{~m}$ away from the hill. Farming along the slope of the hill should also be minimized.

\section{Compliance with ethical standards}

Conflict of interest I, the corresponding author hereby declare that this study was solely sponsored by me, the author. I declare that there is no conflict of interest.

\section{References}

1. Hadji R, errahmane Boumazbeur A, Limani $Y$, Baghem $M$, el Madjid Chouabi A, Demdoum A (2012) Geologic, topographic and climatic controls in landslide hazard assessment using GIS modeling: a case study of Souk Ahras region, NE Algeria. Quat Int 302:224-237. https://doi.org/10.1016/j.quaint.2012.11.027

2. Hungr O, Evans SG, Hutchinson I (2001) A review of the classification of landslides of the flow type. Environ Eng Geosci 7(3):221-238

3. Cruden DM (1991) A simple definition of a landslide. Bull Int Assoc Eng Geol 43(1):27-29

4. European Geosciences Union (2018) Landslides triggered by human activity on the rise. Science daily. Science daily, 23 Aug 2018. www.sciencedaily.com/releases/2018/08/1808230920 49.htm

5. Xu C, Dai FC, Yao X, Chen J, Tu XB, Cao YB, Xiao JZ (2010) GIS based certainty factor analysis of landslide triggering factors in Wenchuan earthquake. Chin J Rock Mech Eng 29(Z1):2972-2981
6. Crosta GB, Frattini P (2003) Distributed modelling of shallow landslides triggered by intense rainfall. Nat Hazards Earth Syst Sci 3(1/2):81-93

7. Zêzere JL, Ferreira AB, Rodrigues ML (1999) Landslides in the north of Lisbon Region (Portugal): conditioning and triggering factors. Phys Chem Earth Part A 24(10):925-934

8. Petley DN (2009) Environmental hazards: assessing risk and reducing disaster, 5 th edn. Routledge, London

9. Froude MJ, Petley DN (2018) Corrigendum to "global fatal landslide occurrence from 2004 to 2016". Nat Hazards Earth Syst Sci 2019(18):2161-2181. https://doi.org/10.5194/nhess -18-2161-2018-corrigendum

10. Abebe B, Dramis F, Fubelli G, Umer M, Asrat A (2010) Landslides in the Ethiopian highlands and the rift margins. J Afr Earth Sci 56:131-138. https://doi.org/10.1016/j.jafrearsci .2009.06.006

11. Sendir H, Yılmaz I (2002) Structural, geomorphological and geomechanical aspects of the Koyulhisar landslides in the North Anatolian Fault Zone (Sivas, Turkey). Environ Geol 42:52-60. https://doi.org/10.1007/s00254-002-0528-9

12. Castellanos Abella EA(2008) Multi-scale landslide risk assessment in Cuba. International institute for geo-information science and earth observation. ITC, Enschede, The Netherlands

13. Onagh M, Kumra VK, Rai PK (2012) Landslide susceptibility mapping in a part of Uttarkashi district (India) by multiple linear regression method. Int J Geol Earth Environ Sci 2(2):102-120

14. Oluwole J (2017) Okemesi creep disaster: Ekiti govt urges residents to move $300 \mathrm{~m}$ from Agboona Hill, p 2. Premium Times, Nigeria. 24 Sept 2017. http://www.premiumtimesng.com

15. Igbokwe Jl, Akinyede JO, Dang B, Alaga T, Ono MN, Nnodu VC, Anike LO (2008) Mapping and monitoring of the impact of gully erosion in southwestern Nigeria using satellite remote sensing and geographic information system. Int Arch Photogramm Remote Sens Spat Inf 38:113-126

16. Okuh D, Osumgborogwu IE (2019) Adjustments to hazards of gully erosion in rural southeast Nigeria: a case of Amucha communities. Appl Ecol Environ Sci 7:11-20

17. Okagbue CO (2003) Stability analysis of a slip-debris flow in the Ogbajalala Hills of Benue State, Nigeria. Nat Hazards 2(2):143-153

18. Nwajide CS, Okagbue CO, Umeji AC (1988) Slump debris flows in the Akovolwo mountains area of Benue State, Nigeria. Nat Hazards 1:145. https://doi.org/10.1007/BF00126611

19. Varnes DJ, Radbruch-Hall DH, Savage WZ (1989) Topographic and structural conditions in areas of gravitational spreading of ridges in the western United States: U.S. geological survey professional paper 1496, p 28

20. Bovis MJ, Evans SG (1995) Rock slope movements along the Mount Currie 'fault scarp', southern Coast Mountains British Columbia. Can J Earth Sci 32(12):2015-2020

21. McCalpin JP, Irvine JR (1995) Sackungen at the Aspen Highlands ski area, Pitkin County, Colorado. Environ Eng Geol 1(3):277-290

22. Thompson SC (1997) Probable gravitational (nontectonic) origin for two conspicuous ridge-top scarps in southern Coast Mountains, British Columbia. EOS Trans Am Geophys Union 78(17):S316-S317

23. Johnson PL, Cotton WR (2005) The Santiago landslide and associated ridge-top graben (sackungen): implications for paleoseismic landslide studies. Geol Soc Am Environ Eng Geosci 11(1):5-15

24. Okunlola OA, Okoroafor ER (2009) Geochemical and petrogenetic features of Schistose rocks of the Okemesi fold belt, Southwestern, Nigeria. RMZ Mater Geoenviron 56(2):148-162

25. Odeyemi IB (1992) The Ifewara fault in southwestern Nigeria, its relationship to fracture zone and seismicity along the Nigerian coast. Kluwer Academic Publishers, Dordrecht 
26. Odeyemi IB (1993) A comparative Study of remote sensing images of the structure of the Okemesi fold belt, Nigeria. ITC J 1931(1):77-81

27. Affaton P, Rahaman MA, Trompette R, Sougy J (1991) The Dahomeyide Orogen: tectonothermal evolution and relationships with the Volta Basin. In: Dallmeyer RD, Lécorché JP (eds) The West African orogens and circum Atlantic correlatives. IUGS-IGCP-UNESCO project 233. Springer, Berlin, pp 107-122

28. Oluyide $P O$ (1988) Structural trends in the Nigerian basement complex. In: Oluyide PO, Mbonu WC, Ogezi AE, Egbuniwe IG, Ajibade AC, Umeji AC (ed) Precambrian geology of Nigeria, geological survey agency of Nigeria, Kaduna, pp 93-98

29. Okonkwo CT (1992) Structural geology of basement rocks of Jebba area, Nigeria. J Min Geol 28(2):203-209

30. Hubbard FH (1975) Precambrian crustal development in Western Nigeria; indications from Iwo region. Geol Soc Am Bull $86: 548-560$

31. Ako BD, Ajayi TR, Alabi AO (1978) A geo-electrical study of Ifewara area. J Min Geol 1975(15):84-89

32. Boesse JM, Ocan OO, Rahaman MA (1989) Lithology and structures of the Ife-llesha area (abstract). In: The 25th annual conference. Nigerian Mining and Geosciences Society Ibadan, pp 6-7

33. Folami SL (1992) Interpretation of aeromagnetic anomalies in Iwaraja area southwestern Nigeria. J Min Geol 28(2):391-396

34. Klemm DD, Schneider W, Wagner B (1984) The Precambrian metavolcano-sedimentary sequence east of Ife and llesha/SW Nigeria. 'A Nigerian greenstone belt'? J Afr Earth Sci 2(2):161-176

35. Wright JB, Hastings DA, Jones WB, Williams HR (1985) Geology and mineral resources of West Africa. George Allen and Unwin, London, $\mathrm{p} 187$

36. Zerere Jl, Trigo RM, Trigo IF (2005) Shallow and deep landslides induced by rainfall in the Lisbon region (Portugal): assessment of relationships with the North Atlantic oscillation. Nat Hazards Earth Syst 5:331-344

37. Oyinloye AO, Odeyemi IB (2001) The geochemistry, tectonic setting and origin of the massive melanocratic amphibolite in the Ilesha schist belt, southwestern Nigeria. Global J Pure Appl Sci 7(1):85-90

38. Anifowose AYB (2004) Remote sensing analysis of IfewaraZungeru mega linear in Nigeria. PhD thesis, Federal University of Technology, Akure, Nigeria, p 169

39. Rahaman MA (1988) Recent advances in the study of the basement complex of Nigeria. In: Precambrian geology of Nigeria. Geological Survey of Nigeria, pp 11-43

40. Caby R, Boesse JM (2001) Pan African nappe system in southwestern Nigeria: the Ife-llesha schist belt. J Afr Earth Sci 33:211-225

41. Yalcin AS, Reis AC, Aydinoglu T, Yomralioglu R (2011) A GIS-based comparative study of frequency ratio, analytical hierarchy process, bivariate statistics and logistics. CATENA 85:274-287

42. Lee $S$, Kyo-Young S, Hyun-Joo O, Jaewon C (2012) Detection of landslides using web-based aerial photographs and landslide susceptibility mapping using geospatial analysis. Int J Remote Sens 33(16):4937-4966

43. Ayonghe SN, Ntasin EB (2008) The geological control and triggering mechanisms of landslides of the 28th July, 2003 within the Bamboutos Caldera, Cameroon. J Cameroon Acad Sci 7(3):191-204

44. Yilmaz I (2009) Landslide susceptibility mapping using frequency ratio, logistic regression, artificial neural networks and their comparison: a case study from Kat landslides (Tokat-Turkey). Comput Geosci 35(6):1125-1138
45. van Westen CJ, Castellanos E, Kuriakose SL (2008) Spatial data for landslide susceptibility, hazard, and vulnerability assessment: an overview. Eng Geol 102(3-4):112-131, ISSN 0013-7952. https:// doi.org/10.1016/j.enggeo.2008.03.010

46. Conforti M, Stefania P, Gaetano R, Francesco S (2014) Evaluation of prediction capability of the artificial neural networks for mapping landslide susceptibility in the Turbolo river catchment (northern Calabria, Italy). CATENA 113:236-250

47. Dai A, Wigley TML, Boville BA, Kiehl JT, Buja LE (2001) Climates of the twentieth and twenty-first centuries simulated by the NCAR climate system model. J Clim 14(4):485-519

48. Geomatics, P.C.I. (2005) PCI Geomatica User Guide

49. Mondal T, Jain A, Sardana HK (2011) Automatic craniofacial structure detection on cephalometric images. IEEE Trans Image Process 20(9):2606-2614

50. Argialas DP, Mavrantza OD (2004) Comparison of edge detection and Hough transform techniques for the extraction of geologic features. Int Archiv Photogramm Remote Sens Spat Inf Sci 34:790-795

51. Rahnama M, Gloaguen R (2004) TecLines: a MATLAB-based toolbox for tectonic lineament analysis from satellite images and DEMs, part 2: line segments linking and merging. Remote Sens 6:11468-11493

52. Dinesh AC, Markose VJ, Jayappa KS (2014) Linfo-a visual basic program for lineament density, frequency and intersection density analysis. Earth Sci Inf 7(3):197-203

53. Tam VT, De Smedt F, Batelaan O, Dassargues A (2004) Study on the relationship between lineaments and borehole specific capacity in a fractured and karstified limestone area in Vietnam. Hydrogeol J 12(6):662-673

54. Greenbaum D (1985) Review of remote sensing applications to groundwater exploration in basement and regolith. British Geological Survey, Notingham, p 63

55. Twiss RJ, Moore EM (1992) Structural Geology. Freeman, New York, pp 1-532

56. Ercanoglu M, Gokceoglu C (2002) Assessment of landslide susceptibility for a landslide-prone area (north of Yenice, NW Turkey) by fuzzy approach. Environ Geol 41:720-730

57. van der Pluijm BA, Marshak S (2003) Earth structure: an introduction to structural geology and tectonics, 2 nd edn. W. W. Norton \& Company, $672 \mathrm{pp}$

58. Jones KH (1998) A comparison of algorithms used to compute Hill slope as a property of the DEM. Comput Geosci 24(4):315-323

59. Uromeihy A, Mahdafivar MR (2000) Landslide hazard zonation of Khorshrostam area, Iran. Bull Eng Geol Environ 58:207-213

60. Zerere JL, Trigo RM, Trigo IF (2005) Shallow and landslides induced by rainfall in the Lisbon region Portugal: assessment of relationships with the North Atlantic oscillation. Nat Hazard Earth Syst Sci 5:331-344

61. Dyer R (1988) Using joints to estimate paleostress ratios. J Struct Geol 10(7):685-699

62. Gupta V (2005) The relationship between tectonic stresses, joint patterns and landslides in the higher Indian Himalaya. J Nepal Geol Soc 31:51-58

Publisher's Note Springer Nature remains neutral with regard to jurisdictional claims in published maps and institutional affiliations. 